\title{
No Save Place for Girls: Study on Sexual Harassments and Violence Against Girls in Indonesia
}

\author{
Dr. Bagong Suyanto \\ Department of Sociology, Faculty of Social and Political Sciences \\ Airlangga University. Jl. Airlangga 4-6, Surabaya 60286, Indonesia
}

\begin{abstract}
This study investigates the incidents of sexual harassments and violence against girls in Indonesia. Based on this research, girls are more likely to become victims of harassment and sexual violence due to their socially weak position and the domination of patriarchal culture. Therefore, they are easily intimidated, violated, and fooled by the perpetrators. Basically this paper is resulted from a qualitative study by analyzing news data from two mass medias (Jawa Pos and Surya) during January 2012- August 2013, and previous studies on sexual harassment against children. In order to provide a comprehensive analysis, this paper uses the concept of gender-based power relations. Using the news media coverage and field study in this area, this paper examines types of harassments and violences against girls in Indonesia and analyse the causes of sexual violences against teenage girls in contemporary Indonesia. I also argue that the patriarchal values and gendered bias system appear to be the main hurdle for women, especially teenage girls, in Indonesia to resist and being saved from the violence actions sexually and predominantly done and accused by the men, especially the girls' father. When wise words saying "the kindest and safest man for girl is her father," this words seem do not occur for unfortunate girls studied in this paper."
\end{abstract}

Keyword: sexual harassment, violence, patriarchal culture

\section{INTRODUCTION}

Indonesia is currently in emergency child protection. This statement is not exaggerating because cases of violence against children, especially sexual abuse, reported in mass media are getting more devastating. Almost everyday the mass media report sexual violence against girls. Statistically, in Indonesia it is estimated that on the average, 5 to 6 women are raped per day or in other words at least one case of rape occurs every 4 hours. It is even more alarming that often the victims are children. There was even a victim who was not even 2 years old.

In his research conducted in Indonesia within the period of 1994 to 1996, Irwanto et. al. (1999) found that the majority of rape victims were children. In fact, it was estimated that $60 \%$ of rape victims were girls under the age of 11 . Meanwhile, a study conducted by Kalyanamitra Foundation involving 9 printed media in Java found that during 1994, 75\% of 185 cases of rape occurred to girls under the age of 17 (Edriana, Kompas, August 1, 1995). Most of the perpetrators (74\%) were known by the victim. Some rapes involved more than one perpetrator. A study conducted by Hariadi \& Suyanto et al (2000) in which the data were taken from Jawa Pos during 1993 to 1994 found that as many as 49.1\% of rape victims were children under the age of 14 , and even $14.2 \%$ of them were under the age of 8 .

Why are girls potential victims of sexual crimes? In addition to the perpretator's mental depravity, psychologically and physically children are generally very vulnerable and can easily become the victims of rape. A study conducted by the Institution of Research and Community Service of Universitas Airlangga in East Java (1992) found that mostly sexual violence involved 
threat and forcefulness (66.3\%). However, some rapists usually tried to persuade their victims $(22.5 \%)$ or used drugs $(5.1 \%)$. Often, a thousand to five thousand rupiahs or candy was enough to persuade the children. The rapist then tricked his victim so that the perpetrator could molest or sexually assault his victim (Hariadi \& Suyanto 2000).

Data from the Indonesian Child Protection Committee (KPAI) in 2011 showed that in Indonesia there were 2,275 cases of child abuse, in which 887 cases were sexual ones. In 2012, as many as 3,871 cases of violence against children were reported, and 1,028 of them were sexual violence against children. During January-February 2013, the KPAI recorded a total of 919 cases of violence against children, in which 216 cases were sexual violence.

This article does not only aim to identify the profile of the perpretators and children as the victims of sexual violence but also examine the area of sexual violence and the problematic situations emerging as girls deal with male superiority.

\section{METHODS}

This research is qualitative descriptive study utilizing and analyzing news in mass media and previous studies on sexual violence against children. Purposively, the mass media determined as the sources of information in this study were Jawa Pos and Surya. Both daily news were selected as they intensively published features and news related to sexual harrassment and violence against girls.

Data on sexual violence analyzed in this study were limited to the cases reported in mass media during the year of 2012 to August 2013. The cases of sexual harrassment and violence analyzed were limited to the ones in which the victims were girls under the age of 18. In order to simplify the process of data collection and tabulation, a semi-structured instrument of data collection had been prepared prior to data collection. Thus, although the possible answers or types of case had been determined, new categories and types of classification might be proposed in accordance with the data obtained. This study has successfully resported 116 cases of sexual harassment and violence against girls occurred during the year of 2012 to August 2013 in a variety of areas reported in Jawa Pos and Surya.

\section{LITERATURE REVIEW}

Sexual harrassment and rape to girls are basically two forms of sexual violence and violation of children's rights, yet ironically sexual harrassment and rape to girls continue to occur and may occur to anyone. Sexual harassment here is defined as giving oral, written or physical sexual attention to woman; the attention is involuntary, yet it must be accepted as fairness (Marzuki et. al. 1995). Rape is forcible sexual intercourse which harms the victim. In other words, rape can be defined as an attempt of a man to vent out his sexual lust to the victim (usually female) in a way that violates the moral and/or applicable laws (Wignjosoebroto 1991). Thus, rape is forcible sexual intercourse to a woman without consent or conscious will of the woman.

To the victim, rape is an affliction that is more painful than just losing property. The victim generally experiences untold psychological trauma and get a stigma as a rape victim. A study conducted by Linda E. Ledray to rape victims found that 2-3 hours after the rape: $96 \%$ of victims suffered from continuous shaking and shivering, 68\% experienced dizziness, 68\% had severe muscle spasms, and 65\% got severe headache and pain. Meanwhile, for the period of post-rape, it was found that: $96 \%$ of the victims had anxiety, $96 \%$ suffered experienced psychological fatigue, $88 \%$ had continuous anxiety, $88 \%$ perceived that they were threatened, and $80 \%$ perceived that they were terrorized by their situation (Marzuki et. al. 1995). 
Furthermore, if the victims of the rape are children, then, chances that they can recover is even smaller. They are likely to suffer from severe trauma (Gelles 1982). Their future is destroyed, and for those who can not bear the burden, committing suicide appears to be the only option. In most cases, the victims can no longer have proper sexual intercourse as they suffer from vaginismus, in which the vaginal wall muscles are always contracting during sexual intercourse, making penetration difficult. In fact, dyspareunia may occur in some cases; pain that emerges during sexual intercourse (Setiabudi, Kompas, 1 August 1995).

Sexual harrassment and rape are not merely crimical case. In order to have an in depth understanding on the causes and impacts of sexual violence on women, this matter should be placed in a broader context, in which the position of women and their behavior are socially defined and controlled. It means, the causes behind a rape are not only an expression of male's unbearable depraved lust but also the feeling of being stronger and more powerful over women (Jackson \& Jones 1998).

Theoretically, it can be said that sexual harassment and violence against women by men are basically an extremely complex phenomenon, growing in gender-based power relations, sexuality, self-identity, and influenced by social institutions developed in the community (Sularto 2000). Sexual violence is, in many ways, understood and considered as an extension of the belief continuum that entitles men to control women's behavior, making women lack of freedom of sexual life and reproductive roles, as, as in the symbolic representation and the ritual of sexual intercourse (Brooks 2008).

\section{RESULTS AND DISCUSSION}

In terms of morality, values and social norms, and laws, sexual harassment and rape are clearly despicable, and thus should be eradicated. Eventhough rapists are sentenced to jail for decades even to death, the number of such cases is not decreasing. Such crime becomes more brutal and inhumane. Children as the victims of rape are not only sexually abused and taken their virginity or forced not to report the crime but sometimes are also persecuted, mistreated, and even killed to eliminate clues leading to the perpetrator. Rape and murder are crimes that are often carried out in sequence.

The potential victims of rape are not always women in sexy dress. Rape and the victims are just like what an advertisement says: "it can happen anytime, anywhere, and to anyone". However, cases of sexual harassment and rape are generally potential to happen to women who are physically and psychologically weak. Evidences suggest that girls are always more at risk than adults to be victims of sexual assault. A study conducted by Kalyanamitra (1999) during 19941996 found that approximately $60 \%$ of the victims of rape reported in media were children. In addition, it turned out that rape was likely to happen in victims' own house instead of a desolate, dark and dangerous place. Mosse (1993) clearly stated that the most dangerous place for women, around the world, is their own house. In short, previously rape was seen as a crime committed by abnormal man who was unable to control his sexual lust, now it is increasingly recognized that rape can be committed by anyone, including normal man, because basically the motive is the mechanism of control and intimidation.

Until today, the exact number of cases of sexual violence has never been clear. Many cases of sexual violence against women were never revealed publicly, making it a dark number. However, a criminologist, Purniati Mangunsong, estimated that at least 1,500 to 2,000 cases of sexual violence occur every year in Indonesia (Irwanto et. al. 1999). As stated by Kalyanamitra that $60 \%$ of rape victims in Indonesia were children, it was estimated that the number of rape occurred to children in Indonesia was no less than 900 to1200 cases (Irwanto et. al. 1999). 
However, this is not $100 \%$ accurate. Yet, if all women were honest and had the courage to report harrassment or sexual violence occurred to them or around them, the number could be much greater. For instance In USA, in which the women movement is advanced, it is reported that rape occurs every six minutes.

Apart from the question of the accuracy of the presented data, sexual abuse and rape as a form of sexual aggression with forcefulness as well as threat is basically a form of crime that is very disturbing, creating traumas for the community-especially for the victims. In many identified cases, it needs to be realized that sexual violence generally is not only about sexual behavior and assault directly addressed to the victims but also the expression of sexual signs and language. On the other hand, harassment and sexual violence against children may be in a form of trading girls for sexual purposes, commercial sexual exploitation of children, or obvious direct sexual abuse and assault in the form of rape (Suyanto et. al. 2000).

Rape is not always preceded by threat and violence. Evidences have shown that rapists always use a variety of reasons and ways to deceive their victims such as seduction, threat to stop funding creating financial dependency on the rapists, fraud, and if it all fails, threat of violence. As reported in mass media, rape victims generally do not perform physical resistance due to fear and helplessness. Commonly the victims are relatively weak, unprotected, or unable to protect themselves. In fact, they may even have a predisposition to let themselves under the control of the rapist. They are, for example, easily persuaded, seduced and invited to events that do not seem harmful. Such situations put the victims in a very vulnerable position (Jackson 1986). It can be understood if a naive country girl, in her first time in a big city, is unsuspecting a stranger who offers to escort her. The stranger may seem kind hearted but he is acually a bad guy. Similarly, how could 7-10 year old girls refuse an offer of delicious sweets from their neighbors whom they have known or from their own teacher they respect.

Sexual harassment and rape are basically a part and forms of gender related violence. It means, the two forms of violation of women's rights are performed not only due to spontanity or a desire to vent out the libido of depraved men but also due to the value or gender ideology that put women and girls in marginal and subordinate position. In many cases of rape, the one to blame by the public is the victim as they are considered as temptress or women who can not take care of herself. Although the public also blame the rapists for what they do, the public regard the rape as men's 'normal' mistake. (Saptari \& Holzner 1997, p. 232).

Commonly, people identify potential victims of rape as those having been labeled as "not a good girl" or those who deserve it. Even when the victim is "a good girl", the public question: how the victim dressed at the time of the rape, how the attitude of the victim is. In short, the questions are always about the sexual morality of the victim - in this case, women. As the rapist is a man, rape is usually accepted as something normal. The rapist is considered as being out of mind or unable to control his sexual lust at the time he commits the crime.

In fact, it has to be as admitted that sexual abuse and rape can happen to anyone, anywhere and at anytime. It means that the accusation that women, as the victims, more or less contribute to the occurence of rape as they are flirty is unjustifiable. Sexual harassment and sexual assault to woman, in many cases, occur due to the position of the victim which is structurally weak, vulnerable or helpless, making the perpretator who wants to express his masculinity in an extreme way commit rape. All this time, many evidences suggest that the potential victim of sexual harrassment and sexual assault is generally girls instead of women. In some cases, rape even occurs to elder women. These facts break the prejudice saying that 
the victims are commonly beautiful and sexy women since the victims of sexual assault are girls, even toddlers who have absolutely no relation to sexiness and lust (Suyanto 2013).

Why are girls more likely to become victims of sexual harrasment and violence? The answers to this question are relatively varied and often cumulative. Girls are more likely to be the victims of sexual violence because their position is socially weak; they are easily fooled, and psychologically easily deceived by the perpetrator who tantalizes them with sweets or coins. Moreover, girls are easier to be scared. Many cases show that girls who are the victims of rape experience severe trauma, which turns them into introvert and uncommunicative person real quick, making the incident unknown to people, including their own parents. In addition, perpetrators believe that committing sexual harassment and violence against girls is less risky and likely to be unrevealed.

Table 1: Status and Profession of Rapist

\begin{tabular}{|c|c|c|c|}
\hline \multirow{2}{*}{ No } & \multirow[t]{2}{*}{ Perpetrators of Sexual Violence to Girls } & \multicolumn{2}{|c|}{ Mass Media Coverage } \\
\hline & & Frequency & $\%$ \\
\hline 1 & Law enforcement officers & 3 & $2,6 \%$ \\
\hline 2 & Father & 13 & $11,2 \%$ \\
\hline 3 & Grandfather & 4 & $3,5 \%$ \\
\hline 4 & Sibling/Relatives & 13 & $11,2 \%$ \\
\hline 5 & Public school teacher & 10 & $8,6 \%$ \\
\hline 6 & Quran recital teacher & 4 & $3,4 \%$ \\
\hline 7 & Neighbor & 23 & $19,8 \%$ \\
\hline 8 & Friend & 2 & $1,8 \%$ \\
\hline 9 & Other & 44 & $37,9 \%$ \\
\hline & Total & 116 & $\begin{array}{r}100,0 \\
\%\end{array}$ \\
\hline
\end{tabular}

Source: Jawa Pos and Surya (2012 to August 2013)

Generally, we imagine the perpetrators of sexual harrassment and rape are a cruel person, suffering from mental disorder or having psychological problems, immoral, having no faith in religion, stranger to the victims, savage criminal, and so on. In fact, frequently the perpetrators are common people who appear normal, having a good attitute, known by the victims and even close to the victim. Out of 185 cases of rape investigated by Kalyanamitra, it was found that in most cases (74\%), the rapist is known by the victim - friend, boyfriend, relatives, husband, father, etc - while in $15 \%$ of the cases, the rapist is a stranger to the victim (Taslim et. al. 1998, pp. 34-41).

Objectively, the rapist could be anyone - whether he is a stranger to the victim or not, whether he has a cognation to the victim or not - the most important thing is the rapist is a man and in a society whose social values put women in a subordinate position, any man could commit planned or unplanned rape. Many evidences and studies suggest that rape or other violence against women generally occurs in a society whose social relations are patriarchal and tend to reduce the role of women. Patriarchal here is an ideology in which men hold higher position than women; women should have been controlled by men because women are part of men's property (Prasetyo \& Marzuki 1997).

The study suggests that the status and profession of rapist varies from stranger, teacher, grandfather, relatives, friend, and police officer to victim's own father. Interestingly, the 
perpetrators of harrassment and rape - regardless the status and profession - are generally socially superordinate to the victim. Almost no sexual harrassment and rape reported in mass media committed by the victim's younger brother, the victim's son, the victim's students or those whose status, role and position are subordinate to the victim. Based on in depth investigation, most rapists are superior to their victims, having the power and able to control the situation, such as teacher, father, adult, so it is not exaggerating if it is said that violence against women is basically a reflection of men's power, or the embodiment of women's vulnerability in the presence of men, and even a portrayal of injustice to women. In order to understand the background of the harrassment and rape to girls, the matters should be placed within a broader social context, in which women's position and behaviour are socially defined and controlled (Jackson \& Jones (eds.) 1998).

As in child abuse, the perpetrator is not always a criminal or someone who enjoys himself in a prostitution complex. The data taken from the mass media show that the rapist is often a person who is familiar to the victim, whether he is the victim's neighbor, sibling, relative, teacher, or even the victim's own grandfather or father.

The study suggests that approximately $10 \%$ of harrassment and rape is committed by the victim's own father. Most rapists are the victim's neighbor, sibling, relative, grandfather, and teacher, be it Quran recital teacher or school teacher. Unlike the cases of sexual harrassment in the working environment mostly committed by the employer or boss (Collier, 1998), the results of the study on the cases of rape of girls are similar to previous studies. Previously, it has been evident that approximately $75 \%$ of molesters are close to the victim, whether they are the victim's relative (43\%), acquaintance (33\%) or the member of the victim's nuclear family - including father. Ironically, since the perpetrator is someone who is close to the victim and having a more superior position, especially when the perpetrator is the victim's own biological father, the rape occurs repeatedly over a period of years because the victim does not have the courage report the rape. It is even more appalling that a rape was reportedly committed by the victim's own father with the victim's own mother (Santoso 1999, p. 99).

Generally, sexual abuse takes place in four places. First, the sexual abuse takes place in a place secured from the surrounding's surveillance, particularly in the victim's home. Second, it takes place in a completely open space, away from the reach of social control, such as on a street, in a public place, in a quiet courtyard, in a graveyard, and so on. Third, it takes place in a school or in a lodge. Fourth, it takes place in a 'gray' area in which permissive life is common, such as prostitution complex, hotel or homestay. Prior to rape cases that occur in such area, the victim is deceived, either by persuasion, threat or deception, and then taken to a place in which the social control is sociologically loose.

\section{CONCLUSION}

Sexual harassment and violence are not only a crime, rather they are a product of the culture of gender bias and patriarchal society. Often, rape itself is evidently not a spontaneous act of lust due to the attractiveness of the victim who wears sexy dress or seeks danger by taking a walk in a deserted place.

The assumption that accuse that rape occurs because of the victim's seduction is not true as evidences suggest that the victims are not always a beautiful woman with hourglass-shaped body. The victims, as we all know, are sometimes an old woman, and often innocent children, even toddlers. 
Unlike the assumption that the rapists are those with pathological properties and behavior, the study found that the rapists are often ordinary people who seem normal in their daily lives, are kind, well known and even close to their victims, whether they are the neighbors, siblings, relatives, teachers, or even the victim's own grandfather or father. Moreover, rape does not only take place in a troubled place, rape often takes place at home and be done with careful planning. Rape does not only take place in a deserted area beyond the control of the community, rather it often takes place at home which is supposed to be the safest place for girls.

As a social issue, we realize that sexual harrassment and violence are still vague, due to the lack of thorough data regarding the number and the crime scene. Possibly, almost all cases of adultery, rape and other crimes against public decency exposed by the media have been handled properly by law. However, other cases remain unsolved and have not been reported to apparatus (dark number) - just like an iceberg: only few cases are reported, but the real number is much greater - all of them have not been handled properly.

There is a strong impression that in some cases of rape, especially when the rapist is the victim's relatives, or incest, the victim's family usually prefers to keep it low as they believe that the family would be disgraced if the rape is known by public. However, the feeling of the victim and its impact on the victim's future is generally not considered. By keeping it low, the disgrace of the family may not be revealed and slowly be forgotten. However, the psychological pain felt by the victim as a result of sexual violence can never be swept away if it is not taken care by a competent party or institution since early. Cases of women who experience molestation in sexual intercourse, withdrawn herself, or even commit a suicide, often correlate to the victim's dark past -buried for years without proper completion.

It needs to be ascertained that, in order to deal with the victim and prevent further crime against public decency, it does not require a moral action or merely a temporary sympathy to the victim, rather a real action supported by components of the society. Massive campaign against all kinds of violence against girls and the commitment of the government on the future of the victims are required. If the commitment to resolve case of rape is only a discourse, it is like an empty slogan $\left.{ }^{* * *}\right)$.

\section{References}

Brooks, Ann (2008). Posfeminisme \& Cultural Studies. Yogyakarta: Jalasutra.

Collier, Rohan(1998). Pelecehan Seksual: Hubungan Dominasi Mayoritas dan Minoritas. Yogyakarta: Tiara Wacana.

Gelles, J.R. (1982). "Child Abuse and Family Violence", in: Newberger, E.H. (ed). Child Abuse. Boston: Little, Brown and Co.

Irwanto, Farid, Muhammad \& Anwar, Jeffry (1999). Anak yang Membutuhkan Perlindungan Khusus di Indonesia: Analisis Situasi.Jakarta: Kerjasama PKPM Unika Atmajaya Jakarta, Departemen Sosia, dan UNICEF.

Hariadi, Sri Sanituti \& Suyanto, Bagong (eds.) (2000). Anak Perempuan Korban Kekerasan Seksual. Surabaya: Lutfansah Mediatama.

Jackson, Margareth(1986). "Fact of Life or Eroticization of Women's Oppression, Sexology and the Social Construction of Heterosexuality", in: Pat Caplan (ed.). The Cultural Construction of Sexuality. London and New York: Tavistock Publication.

Jackson, Stevi \& Jones, Jackie (eds.) (1998). Contemporary Feminist Theory. New York: New York University Press. Kalyanamitra (1999). Menghadapi Pelecehan Seksual. Jakarta: Kalyanamitra, Pusat Komunikasi dan Informasi Perempuan.

Marzuki, Suparman, Prasetyo, Eko \& Martha, Aroma Elmina (eds.) (1995). Pelecehan Seksual, Pergumulan Antara Tradisi Hukum dan Kekuasaan. Yogyakarta: Pustaka Pelajar. 
Suyanto, B. (2015). No Save Place for Girls: Study on Sexual Harassments and Violence Against Girls in Indonesia. Advances in Social Sciences Research Journal, 2(4) 01-08.

Mosse, Julia Cleve (1993). Half The World, Half a Change, An Introduction to Gender and Development. Oxford: Oxfam.

Prasetyo, Eko \& Marzuki, Suparman (eds.), (1997). Perempuan Dalam Wacana Perkosaan. Yogyakarta: PKBI Yogyakarta.

Suyanto, Bagong et al., (eds.), (2000). Tindak kekerasan Terhadap Anak: Masalah dan Upaya Pemantauannya. Surabaya: Kerjasama LPA Jatim dan UNICEF.

Suyanto, Bagong, (2013). Masalah Sosial Anak. Jakarta: Kencana, Prenada Media Group.

Sularto, St., (2000). Seandainya Aku Bukan Anakmu. Jakarta: KOMPAS bekerjasama dengan World Vision Indonesia.

Saptari, Ratna \& Holzner, Brigitte (1997). Perempuan, Kerja dan Perubahan Sosial, Sebuah Pengantar Studi Perempuan. Jakarta: Grafiti Press.

Santoso, Topo (1999). Krisis dan Kriminalitas Pasca Reformasi. Jakarta: Sinar Harapan.

Taslim, Adrina et al.,(1998). Bila Perkosaan Terjadi. Jakarta: Kalyanamitra, Pusat Komunikasi dan Informasi Perempuan.

Wignyosoebroto, Soetandyo, (1991). "Wanita dalam Masyarakat yang Didominasi Pria dan Perubahan Jaman", Makalah. Seminar Wanita dan Perkawinan pada Pusat Penelitian/Studi Wanita (PPSW) Lembaga Penelitian Universitas Airlangga, Surabaya. 